\title{
27. THERMAL AND HYDROLOGIC PROPERTIES OF OLD OCEANIC CRUST IN HOLE 765D, ARGO ABYSSAL PLAIN, INDIAN OCEAN ${ }^{1}$
}

\author{
David A. Castillo ${ }^{2,3}$
}

\begin{abstract}
With a few exceptions, our knowledge of heat flow within the oceanic lithosphere comes from seafloor measurements using techniques that include sediment probes and coring. Borehole temperature-logging technology has been remarkably successful in continental boreholes, and has only recently been exploited by the ODP community. Borehole temperature measurements are valuable because the data gathered allow us to investigate how heat transfer (conductive and/or convective) varies with depth. For this reason, fine-scale, high-resolution temperature profiles were measured in Hole 765D to document the thermal and hydrologic properties of 140-Ma-old oceanic crust in the Indian Ocean near the northwestern shelf of Australia. Three complete temperature logging runs were conducted employing the new temperature logging tool (TLT), which is now standard logging equipment aboard JOIDES Resolution. The results indicate an average heat flow for the sediment section $(0-932 \mathrm{mbsf})$ of $52.8 \pm 5.7 \mathrm{~mW} / \mathrm{m}^{2}$. This heat flow is slightly higher $\left(\sim 9 \mathrm{~mW} / \mathrm{m}^{2}\right)$ than both regional heat-flow measurements and the heat flow predicted by a conductive cooling model. Temperature profiles for the basalt section ( $932-1195 \mathrm{mbsf}$ ) are each associated with temperature inversions and intervals $(10-50 \mathrm{~m})$ of near-constant temperatures. The computed equilibrium temperature profile is thermally depressed in excess of a few degrees Celsius compared with an expected profile assuming a conductive and steady-state heat-flow regime. The major source of this thermal perturbation appears to be formation fluid that enters the borehole near the sediment/basalt interface and eventually flows downhole and into the basalt formation, presumably through open fractures. The flow is generally restricted to the upper 150 $\mathrm{m}$ of the basalts. Based on these thermal and hydrologic observations, the shallow section of the oceanic crust at this site is believed to be permeable and slightly underpressured (fluid pressure less than hydrostatic).
\end{abstract}

\section{INTRODUCTION}

Most of the oceanic heat-flow data comes from sediment probes that measure thermal properties within the upper several meters of the sediments. These observations have contributed greatly to our understanding of how the oceanic crust cools with age (Parsons and Sclater, 1977) and how hydrothermal circulation plays an active role in cooling young crust (Becker et al., 1989). In general, the oceanic crust cools conductively. This is supported by the good agreement of global heat-flow and bathymetry measurements with predicted heat-flow and bathymetry profiles plotted as a function of the square root of age (Parsons and Sclater, 1977). However, significant heat-flow anomalies exist in the oceanic crust, usually in thinly sedimented and young (up to 50 Ma old in extreme cases) crust. It is believed that these departures from the conductive model are related to convective systems that reside within the upper $1 \mathrm{~km}$ or so of the crust (Anderson and Hobart, 1976; Langseth et al., 1988).

However, deep borehole observations of temperature and hydrologic processes within the oceanic crust are limited to a few sites, namely Deep Sea Drilling Project (DSDP) Holes 504B and 395A (Hyndman et al., 1976, 1977; Becker et al., 1983, 1984). Fine-scale observations of boreholes in the oceanic environment have recently become available with the advent of high-resolution temperature logging tools (TLTs). This advancement in tool technology allows us to test the assumption of a conductively cooling model, whereby constant heat flow is expected for all depths through the shallow sections of the oceanic crust, and to investigate the evolution of the hydrothermal system with age. Our

\footnotetext{
${ }^{1}$ Gradstein, F. M., Ludden, J. N., et al., 1992. Proc. ODP, Sci. Results, 123 College Station, TX (Ocean Drilling Program).

2 Department of Geophysics, Stanford University, Stanford, CA 94305, U.S.A.

${ }^{3}$ United States Geological Survey, 345 Middlefield Road, Menlo Park, CA 94025, U.S.A.
}

objective was to use repeated fine-scale temperature measurements to explore the thermal and hydrologic properties of $\sim 140$ Ma-old oceanic crust located in the Argo Abyssal Plain, Indian Ocean, during Ocean Drilling Program (ODP) Leg 123 (Fig. 1).

\section{BACKGROUND}

Regional heat-flow measurements in the Indian Ocean were recently compiled by Stein et al. (1988) to include only measurements made in areas of sufficient sediment cover, excluding measurements made in hot-spot areas and oceanic plateaus with continental origins. Based on these criteria, the mean heat flow of about $44 \mathrm{~mW} / \mathrm{m}^{2}$ (Stein et al., 1988) for the Argo Abyssal Plain of the Indian Ocean should be representative of the regional heat flow because the area is covered by more than $1 \mathrm{~km}$ of sediment and therefore is not strongly influenced by convective heat losses. This regional heat flow (Fig. 1) in the Argo Abyssal Plain is close to that predicted for a conductively cooling plate of $140 \mathrm{Ma}$ (Parsons and Sclater, 1977).

Compiled heat-flow measurements (Swift et al., 1988) from the Exmouth Plateau region (continental in origin) show a gradual heat-flow decrease from $\sim 90 \mathrm{~mW} / \mathrm{m}^{2}$ near the Australian shoreline to about $~ 50 \mathrm{~mW} / \mathrm{m}^{2}$ near the flanks of the Gascoyne Abyssal Plain (Fig. 1). Swift et al. (1988) accounted for the progressive decrease in heat flow from the continental interior out to the continent/ocean boundary (Fig. 1), using measured gradient variations and a model that includes conductive heat transfer and radiometric heat production. As will be shown later, the moderately high heat flow from Hole $765 \mathrm{D}$, in comparison to the regional results from the Argo Abyssal Plain area, is consistent with the idea that continental thermal sources active near the Australian margin (or continent/ocean boundary) are contributing to the overall heat flow at Hole 765D (Fig. 1).

\section{TEMPERATURE MEASUREMENTS}

The data analyzed in this study were collected using the TLT designed and built by the Borehole Research Group at Lamont- 


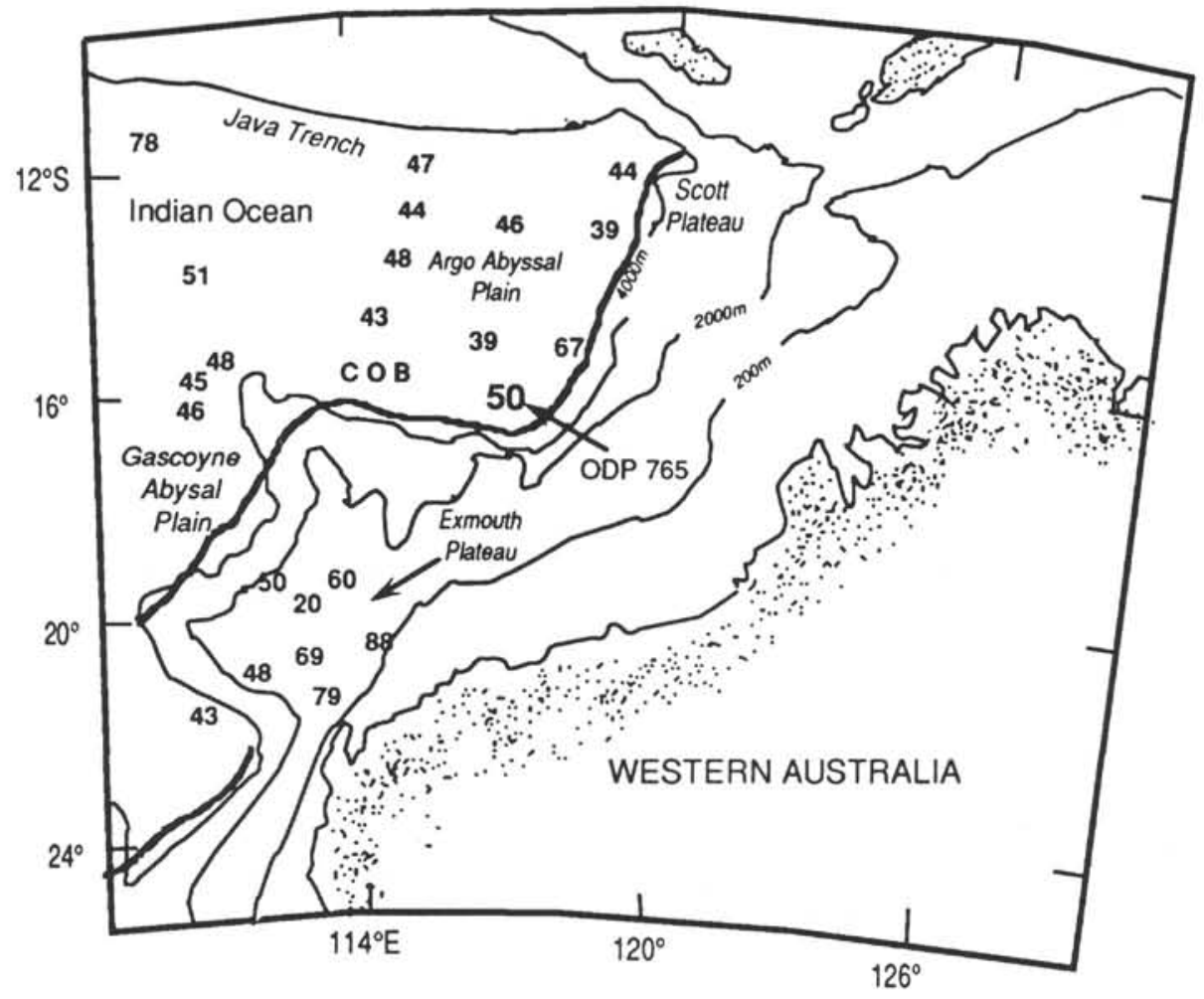

Figure 1. Location of Hole 765D in the Argo Abyssal Plain. In the compilation of regional heat flow for the northeastern Indian Ocean (Anderson et al., 1977; Geller et al., 1983; Swift et al., 1988) the large bold heat flow of $50 \mathrm{~mW} / \mathrm{m}^{2}$ is the result from Hole 765D. The heavy line is the continent/ocean boundary (COB) after Veevers et al. (1985).

Doherty Geological Observatory. The TLT is a low-temperature tool capable of measuring temperatures with two different thermistors and pressure every $0.5 \mathrm{~s}$. This information is stored in the tool's internal memory and later downloaded to a mainframe computer for analysis. One of the temperatures is from a fast-response thermistor, the CRCN, whereas the stable and more accurate temperatures are from the YSI thermistor (Fig. 2). In some cases, the CRCN thermistor was susceptible to drift, and for that reason, temperatures measured with the stable and more accurate YSI thermistor are presented here.

The TLT is operated by simply attaching it to the bottom of a standard logging tool assembly, such as a Schlumberger logging string, borehole televiewer (BHTV), or multichannel-sonic tool. The advantages of using the TLT over probes historically used during DSDP and ODP legs are that near-continuous temperature measurements can be collected without adding to the total logging time and the data can be stored internally and not telemetered up the coaxial cable. Leg 123 was the first ODP leg that successfully used this new tool.

The TLT was deployed on three logging runs in Hole 765D: the seismic-stratigraphy tool string (SS), BHTV, and lithoporosity tool string (LP). Logs were recorded continuously in both the downgoing and upgoing directions, but because the downgoing speed $(1000 \mathrm{~m} / \mathrm{hr})$ was about 3 times the upgoing speed $(300$ $\mathrm{m} / \mathrm{hr}$ ), higher resolution data could be attained by using only the upgoing log. Therefore, only the upgoing log was used in the data analysis.

To convert a temperature-time log to a temperature-depth $\log$, times were merged with the ETIM (time-depth) log from the Schlumberger data. This was done by identifying the time and associated maximum temperature at the bottom of the hole imme- diately prior to logging up from the TLT log (e.g., the temperatures increase going downhole, stabilize at the bottom, then decrease once the TLT begins going uphole). This was the general procedure used for the SS and the LP logs (Ludden, Gradstein, et al., 1990) because these runs were continuous from the bottom of the hole to the seafloor.

Because the BHTV records neither time nor depth, a temperature-depth log for the open-hole basalt section was constructed using a pseudo-ETIM log by noting the BHTV logging speed and beginning depths taken from the surface depth-counter. Using the ETIM and the pseudo-ETIM merging technique was successful for all three logs except where the BHTV was pulled up the well through the casing. To produce a BHTV temperature-depth log in the casing, the hydrostatic pressure readings from the SS and the LP logs were cross-correlated with their respective depths to establish a pressure-depth relationship. This relationship was then used on the BHTV temperature-pressure data in the casing to construct a temperature-depth log.

Illustrated in Figure 3 are the three final temperature-depth profiles that were analyzed to characterize the thermal and hydrologic properties at Site 765 . From 0 to $932 \mathrm{~m}$ below seafloor (mbsf), all temperatures were measured in casing 14 to 20 days after drilling the sediment section. The open-hole measurements (932-1195 mbsf) were in the massive and pillow basalt section and were collected 2 to 13 days after drilling through the basalt. The equilibrium curve was calculated knowing the drilling, circulation, and logging times and using a constant heat-source model originally introduced by Bullard (1947) and later expanded by Lachenbruch and Brewer (1959). Figure 4 illustrates the elapsed time between when drilling and circulation ceased and when the temperature measurements for each log were made. For instance, 


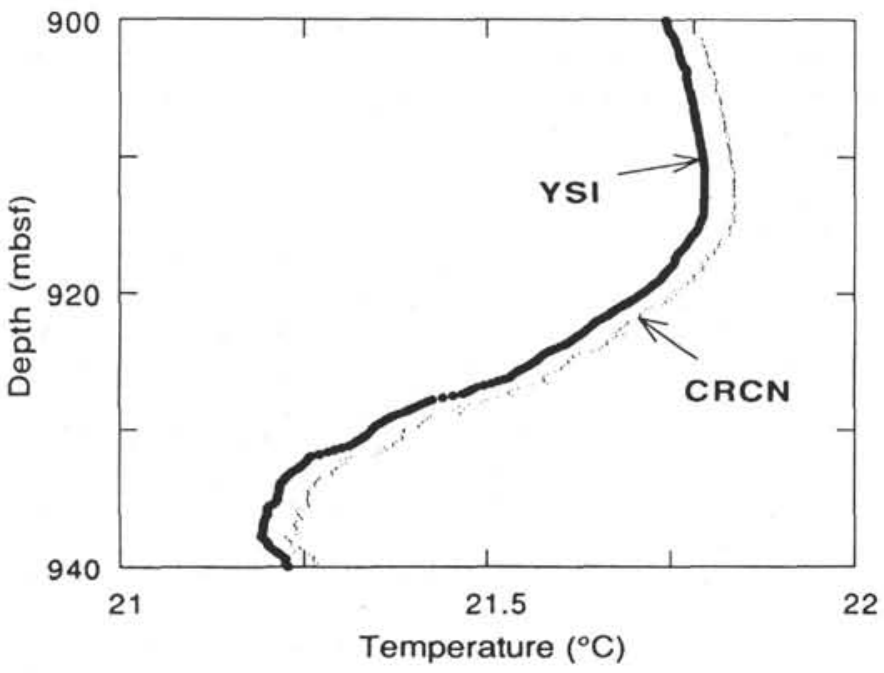

Figure 2. Plot of the fast-response thermistor $(\mathrm{CRCN})$ compared with the more stable and accurate thermistor (YSI) used in the TLT. Only data from the YSI thermistor were used in this study. The temperature inversion at $935 \mathrm{mbsf}$ occurs at the casing shoe and is presumably related to cool formation fluids entering the borehole near the casing shoe or through the sediment/basalt interface.

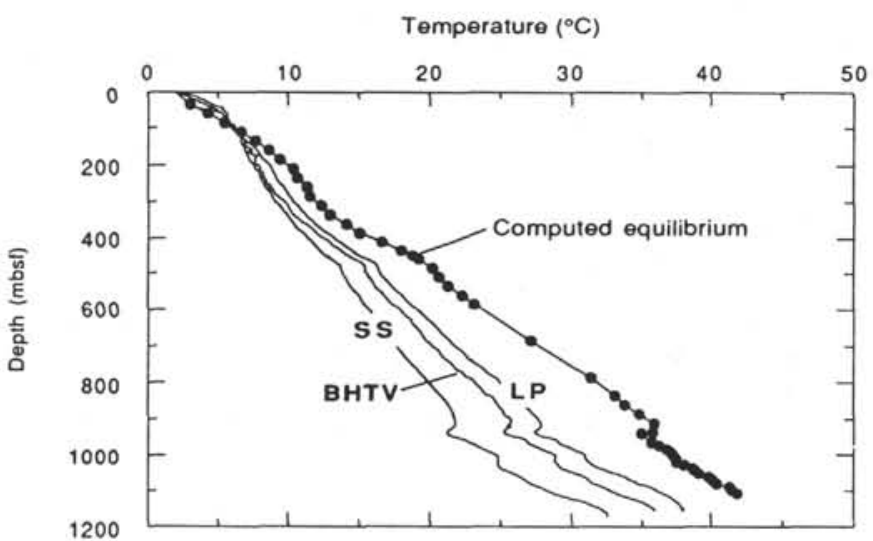

Figure 3. Temperature-depth plots of the SS, BHTV, and LP temperature runs for Hole 765D. Also included is the equilibrium curve based on a conductively cooling model after Bullard (1947) and Lachenbruch and Brewer (1959). From 0 to $932 \mathrm{mbsf}$, all temperatures were measured in casing about 10 days after drilling the sediment section. The open-hole measurements were made in the massive and pillow basalt section (932-1150 mbsf). Note that the curves closely track each other. The "noisy" character of the BHTV run in the casing is attributed to the fast logging speed as the tool was pulled up the hole. The casing shoe was located at 932 mbsf.

bottom-hole temperatures made using the SS, BHTV, and LP were measured at 24,60 , and $95 \mathrm{hr}$, respectively. If the disturbance of the thermal regime from drilling follows a simple heat-conduction model, then repeated measurements at the same depth will eventually yield an equilibrium temperature.

Equilibrium temperatures based on a heat-conduction model can be approximated by plotting the temperature as shown in Figure 5 , extrapolating the curves such that $\ln (t /[t-s])=0$ (i.e., $t=\infty$ ). For any given depth, $t$ would be the total time elapsed since the drill bit penetrated that depth, and $s$ would be the elapsed time between the initial penetration and when drilling and circulation ceased.

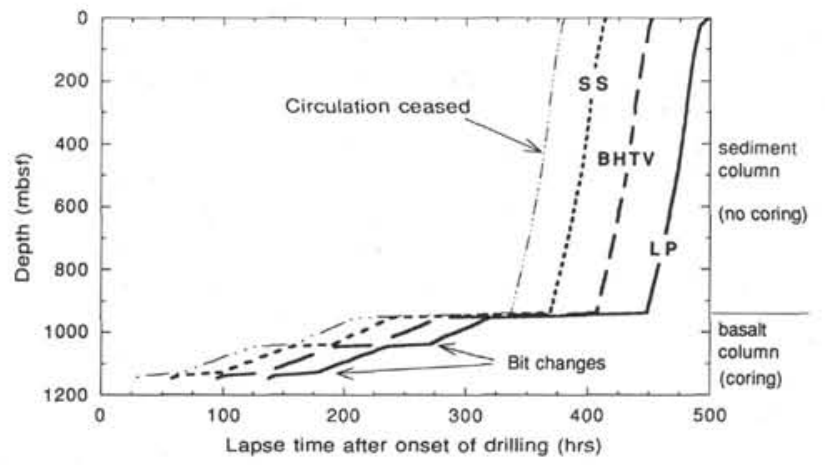

Figure 4. Lapse times used for computing the equilibrium temperatures based on a conductive cooling model using the Bullard method (1947). Times were recorded between the onset of drilling, the cessation of circulation, and the actual temperature measurement. The shortness of elapsed time in the upper approximately $900 \mathrm{~m}$ is due to drilling the sediment section with no coring. Coring did not begin until the basalt section was penetrated and used 3 drill bits.

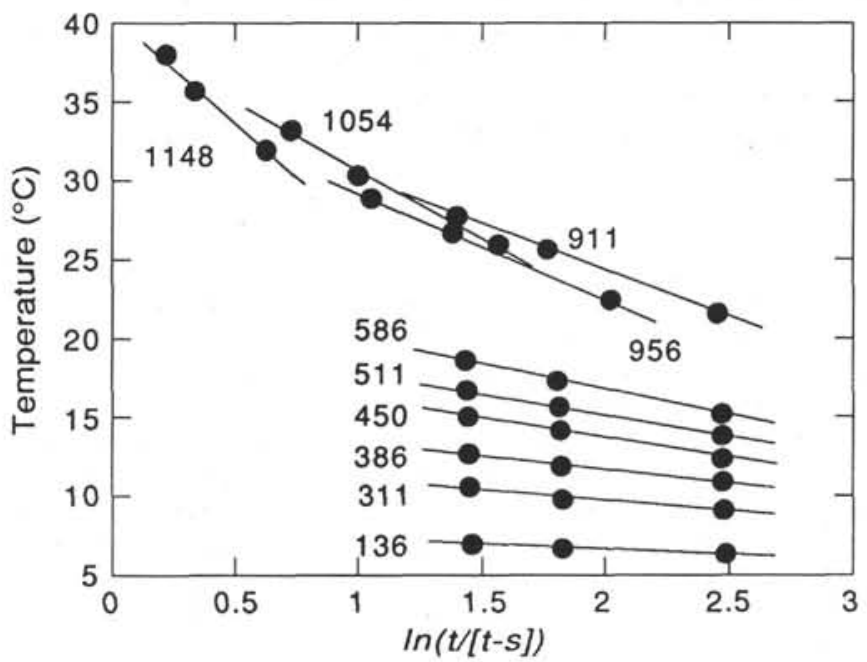

Figure 5. Plot of temperature vs. the function $\ln (t /[t-s])$ for any particular depth, where $t$ is the total time between the actual temperature observation and when the drill bit initially reached the observation depth and $s$ is the elapsed time between the onset of drilling and the cessation of circulation. The equilibrium temperature is determined by extrapolating the function back to zero (i.e., $t=\infty$ ) and reading the temperature intercept. The numbers alongside the best-fitting curve correspond to the measured depth. For clarity, only 10 of the 50 computed curves are shown. The computed equilibrium curve in Figure 3 indicates the depth locations for which equilibrium temperatures were determined.

\section{RESULTS}

The three temperature profiles and the computed equilibrium profile are shown in Figure 3. On the scale of a few hundred meters, temporal similarities between the measured profiles (SS, BHTV, and LP) at Site 765 suggest that the warming process is moderately uniform and progressing toward a state of thermal equilibrium. Minor differences in the temperature profiles with depth warranted subdividing the well into four distinct layers: an uppermost sediment section (0-150 mbsf), middle sediment section (150-450 mbsf), lower sediment section (450-900 mbsf), and, finally, basement basalt section (900-1200 mbsf). The boundaries between each layer occur at abrupt and well-pro- 
nounced changes in the warming trends, associated with major lithologic transitions and differences in thermal conductivities. Further elaboration on this is found in the heat-flow discussion.

In general, the sediment section of the well (cased section) appears to be warming, as expected, based on a conductive heat transfer model. Below the sediment/basalt interface and within the massive and pillow basalts, temperature profiles have a similar shape (Fig. 3). In the basalt section, each profile is characterized by small temperature inversions of up to $2^{\circ} \mathrm{C}$ centered at $935 \mathrm{mbsf}$ (Figs. 2 and 3) and 10- to 50-m intervals of near-constant temperature within the basalt section beginning at about $1000 \mathrm{mbsf}$ (Fig. 3).

For the remainder of this paper, the discussion will focus on using these thermal observations to estimate the overall heat flow for Site 765 and to explore various possibilities regarding the source of the thermal perturbations observed within the basalt section.

\section{Heat Flow}

Heat flux can be calculated knowing the temperature gradient and the corresponding thermal conductivities for the rock across which the temperature measurements were collected. This principle of determining heat flux is based on the implicit assumption that the heat-transfer mechanism is entirely conductive under steady-state conditions. If this assumption is correct, the heat flux, $Q$, can then be adequately described by the following equation:

$$
Q=-\lambda(d T / d z),
$$

where $\lambda$ is the thermal conductivity $\left(\mathrm{W} / \mathrm{m}-{ }^{\circ} \mathrm{C}\right), T$ is temperature, and $z$ is depth. No allowance was made for convective heat transport by water or other fluids. The heat flow was determined for the individual lithologic layers, and the results were then applied to determining the average heat flow within the basalt section.

The thermal gradient $(d t / d z)$ for Site 765 was estimated using the thermal equilibrium profile (Fig. 3), and the thermal conductivities of the core samples were measured routinely throughout most of the hole, except in the interval between 700 and $900 \mathrm{mbsf}$, where efforts were unsuccessful because of the brittle nature of the lithified claystones (Ludden, Gradstein, et al., 1990).

\section{Sediment Section}

The heat flow for Site 756 was determined using a conductive model and two methods: the interval method and the Bullard
(1939) method. These methods were restricted to the cased-hole sediment section because the thermal inversions and isothermal patterns associated with the basalt section strongly suggest that heat transfer is not entirely dominated by conductive cooling processes. A detailed discussion on the basalt section is reserved for later.

The interval method, described by Powell et al. (1988), subdivides the well into distinct intervals corresponding to major lithologic units. The computed equilibrium profile and associated temperature gradients for the entire well are illustrated in Figure 6. The laboratory-measured thermal conductivities (Ludden, Gradstein, et al., 1990) and the corresponding lithologic boundaries used in the interval method for Site 765 are illustrated in Figure 7. Thermal gradients and thermal conductivities were simply averaged for each of these units; results of these heat-flow calculations are shown in Figure 8. Heat flow for Site 765 appears to range from $49.0 \pm 5.4 \mathrm{~mW} / \mathrm{m}^{2}$ to $63.6 \pm 5.7 \mathrm{~mW} / \mathrm{m}^{2}$, where the errors likely reflect uncertainties in the conductivity measurements. For instance, the highest heat flow $\left(63.6 \mathrm{~mW} / \mathrm{m}^{2}\right)$ occurs within the $450-600$ mbsf interval, a well-pronounced lithologic section associated with several alternating layers of unconsolidated and poorly sorted turbidite and debris flows (Fig. 7).

A distance-weighting scheme was employed to estimate the heat flow based on temperature measurements conducted in the sediment section. This scheme merely weighed the result by its interval length. As an improvement over a simple average, results from longer intervals with consistent thermal conductivities and smooth thermal gradients (e.g., $150-450$ mbsf) carried more weight than shorter intervals with unstable thermal properties (e.g., 450-600 mbsf). This distance-weighting scheme for all the layers resulted in a heat flow of $52.8 \pm 5.7 \mathrm{~mW} / \mathrm{m}^{2}$.

The Bullard (1939) method uses the same steady-state, conductive heat-flow model, but employs a quantity called the thermal resistances $(\Delta z / \lambda)$, where $\Delta$ is the layer thickness and $\lambda$ is the thermal conductivity of the layer. The thermal resistances are summed over the lithologically based intervals and plotted vs. the corresponding temperature observed at the base of the interval. If a conductive heat model applies, the plot should form a straight line with a slope $Q$ (heat flow) and an intercept $T_{\mathrm{o}}$ (surface temperature). This relationship can be expressed in the following manner:

$$
T(z)=T_{o}+Q \Sigma\left(\Delta z_{i} / \lambda_{i}\right)
$$

B

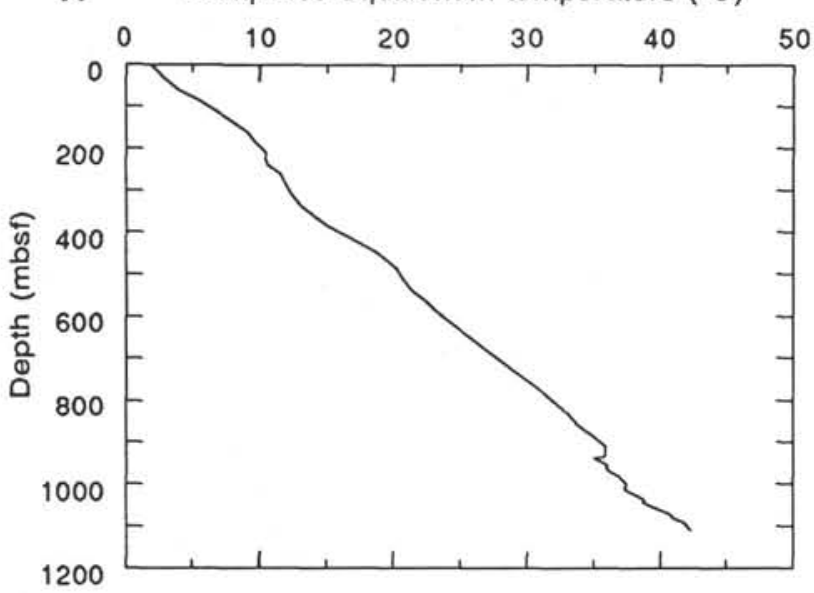
Temperature gradient $\left({ }^{\circ} \mathrm{C} / \mathrm{km}\right)$

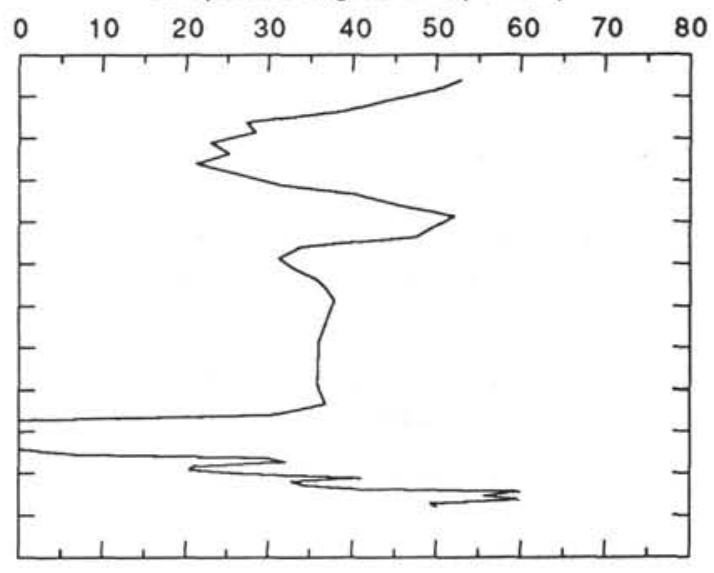

Figure 6. Plots of the thermal equilibrium curve (A) and thermal gradient (B) for Hole 765D. The gradient was determined by sliding a 5-10-m window through the sediment and basalt sections. Note the large gradient changes at 150 and $450 \mathrm{mbsf}$ and within the basalt section ( $932-1150 \mathrm{mbsf})$. 


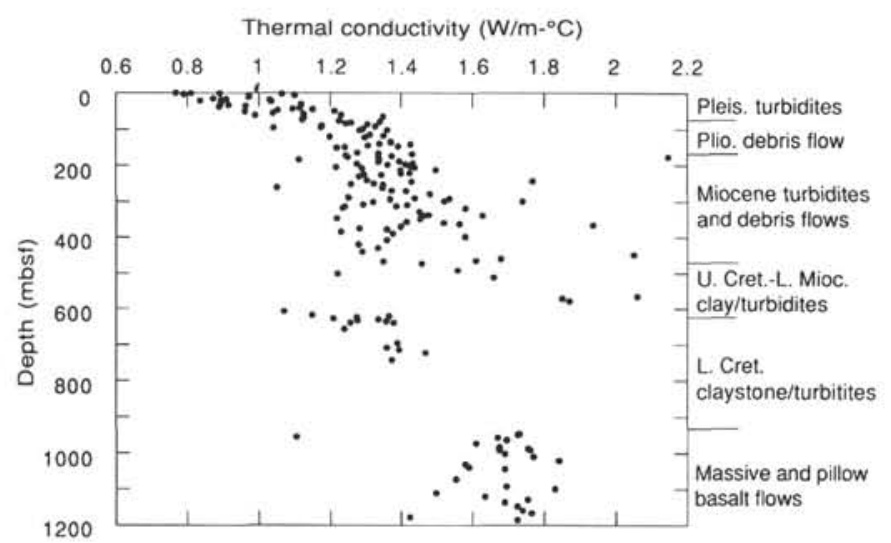

Figure 7. Plot of the thermal conductivity measurements of the core samples compared to the corresponding lithology (generalized) for the Hole 765D. The scatter in the thermal conductivities between 200 and 600 mbsf may be related to the Miocene and Upper Cretaceous turbidite and debris flows. the thermal gradient. Thermal conductivities in the lower sediment section (600-932 mbsf) have been estimated to be about $1.33 \pm 0.1 \mathrm{~W} / \mathrm{m}-{ }^{\circ} \mathrm{C}$ and increase to $1.67 \pm 0.1 \mathrm{~W} / \mathrm{m}-{ }^{\circ} \mathrm{C}$ within the massive and pillow basalts (Fig. 7). If the heat flow for Site 765 is about $52.0 \mathrm{~mW} / \mathrm{m}^{2}$ (averaged between the interval and Bullard methods), the corresponding thermal gradients for the sediment and basalt sections would be 39.1 and $31.1^{\circ} \mathrm{C} / \mathrm{km}$, respectively. The expected temperatures based on these thermal gradients have been plotted, along with the computed thermal equilibrium profile (Fig. 11). Clearly, the equilibrium profile (originally based on the conductive model) is thermally depressed. This thermal perturbation is most pronounced between 925 and 1080 mbsf, with temperatures depressed by as much as $2^{\circ} \mathrm{C}$ with respect to the predicted gradient. Below $1080 \mathrm{mbsf}$, the thermal regime is nearly identical to the predicted gradient.

\section{DISCUSSION}

The conductive model assumes that the warming patterns seen in the temperatures profiles are due entirely to heat transfer by
A Thermal equil. gradient $\left({ }^{\circ} \mathrm{C} / \mathrm{km}\right)$

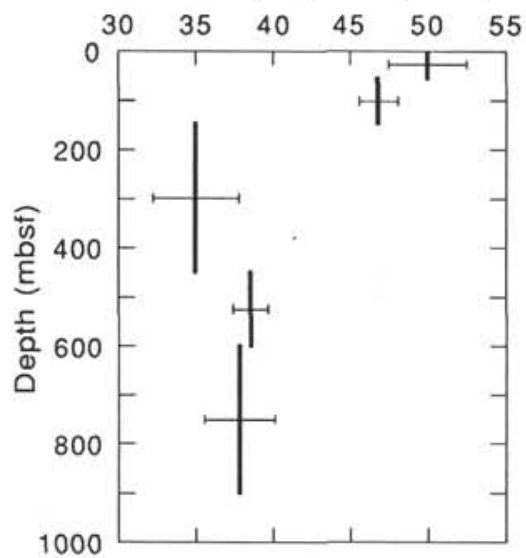

B

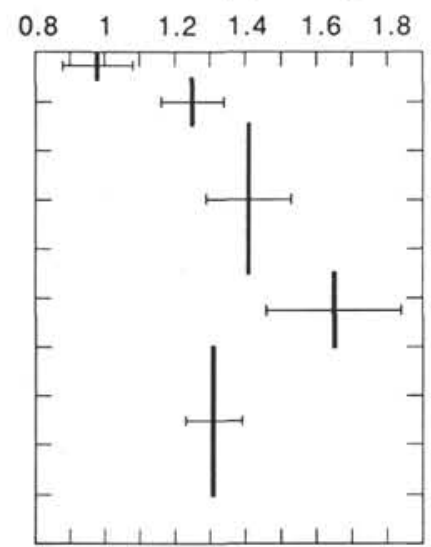

C

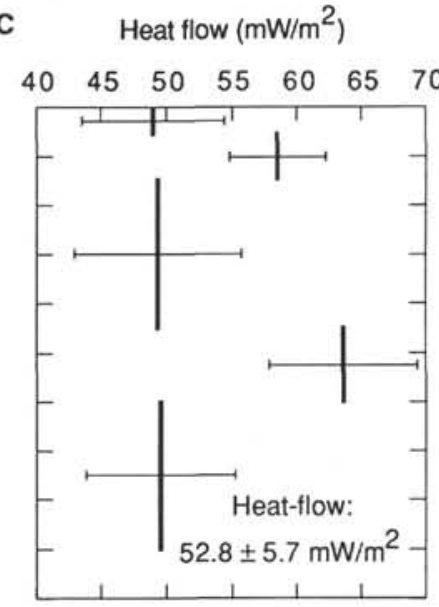

Figure 8. Illustration of heat flow within the sediment section at Hole 765D determined by the interval method (Powell et al., 1988). The well was divided into different layers corresponding to the generalized lithology shown in Figure 7. Associated with each of these layers are the representative thermal gradients (A) and thermal conductivities for the well (B). Error bars for the heat flow (C) are primarily indicative of the scatter within the thermal conductivity measurements. The heat flow determined using a distance-weighted scheme was $52.8 \pm 5.7 \mathrm{~mW} / \mathrm{m}^{2}$.

The Bullard method included the same intervals used for the interval method. The results, shown in Figure 9, indicate that the heat flow in the sediment section is about $51.2 \mathrm{~mW} / \mathrm{m}^{2}$, which is comparable to that attained using the interval method $(52.8 \pm 5.7$ $\mathrm{mW} / \mathrm{m}^{2}$ ). The consistency of results between these two independent methods suggests that heat transfer is dominated by conductive processes, at least within the sediment layer.

The computed heat flow of about $52 \mathrm{~mW} / \mathrm{m}^{2}$ using both the interval and Bullard methods is about $9 \mathrm{~mW} / \mathrm{m}^{2}$ higher than expected for 140-Ma-old oceanic crust (Fig. 10) using a conductive cooling plate model after Parsons and Sclater (1977). The excess heat at this site may be related to continental thermal sources active near the continent/ocean boundary (Swift et al., 1988) that contribute to the cumulative heat flow at Hole 765D (Fig 1).

\section{Basalt Section}

The analysis of heat transfer for the basalt section is closely tied to the assumption that heat flow is constant with depth, with no appreciable heat sources or sinks. Therefore, any change in the thermal conductivity would likewise reflect an inverse change in conduction. This generally holds true for the sediment section, where any uncertainties in heat flow $\left( \pm 5-8 \mathrm{~mW} / \mathrm{m}^{2}\right)$ are probably related to uncertainties in the measured thermal conductivities (Ludden, Gradstein, et al., 1990). However, large uncertainties in the thermal conductivities can not explain the fine-scale temperature perturbations within the basalt section (Figs. 3 and 11), suggesting a conductive heat transfer model may not be completely applicable and, therefore, other hydrodynamic processes that affect the equilibrating process may be active.

Important comparisons may be made between Site 765 and borehole temperature measurements from five DSDP holes: Hole 504B near the Costa Rica Rift (Becker et al., 1984, 1989); Holes $335,396 \mathrm{~B}$, and $395 \mathrm{~A}$ on the flank of the Mid-Atlantic Ridge (Hyndman et al., 1976, 1977; Becker et al., 1983); and Hole 454A in the Mariana Trough (Uyeda and Horai, 1982). The temperatures for each of these wells were nearly constant from the seafloor through the casing or drill pipe down to the upper basalt section, where they suddenly increased toward temperatures expected from heat-flow estimates. In these cases, these investigators postulated that the fluids first flowed downward from the seafloor through the cased section and then out of the casing and 


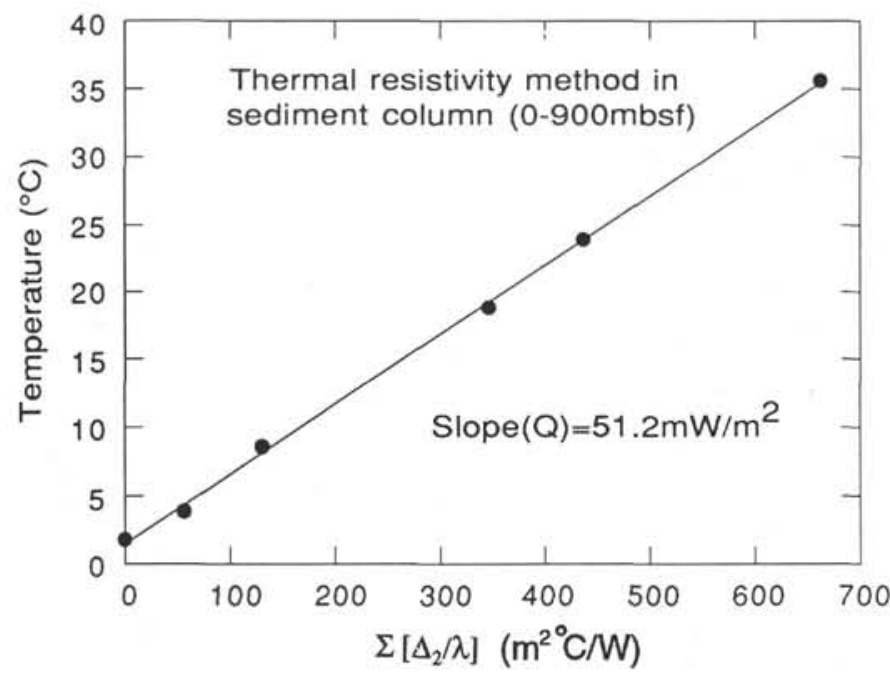

Figure 9. Plot of temperature $\left({ }^{\circ} \mathrm{C}\right)$ vs. thermal resistance $\left(\Delta z / \lambda_{i}\right)$ where $\Delta z$ is the layer thickness and $\lambda_{i}$ is the thermal conductivity of the $i$ th layer (Bullard method) for the sediment section. The slope, $Q$, which is equivalent to the heat flow, turns out to be $51.2 \mathrm{~mW} / \mathrm{m}^{2}$. The Bullard method used the same lithologic layers as those used in the interval method (see text). Note that both methods arrived at similar heat-flow values.

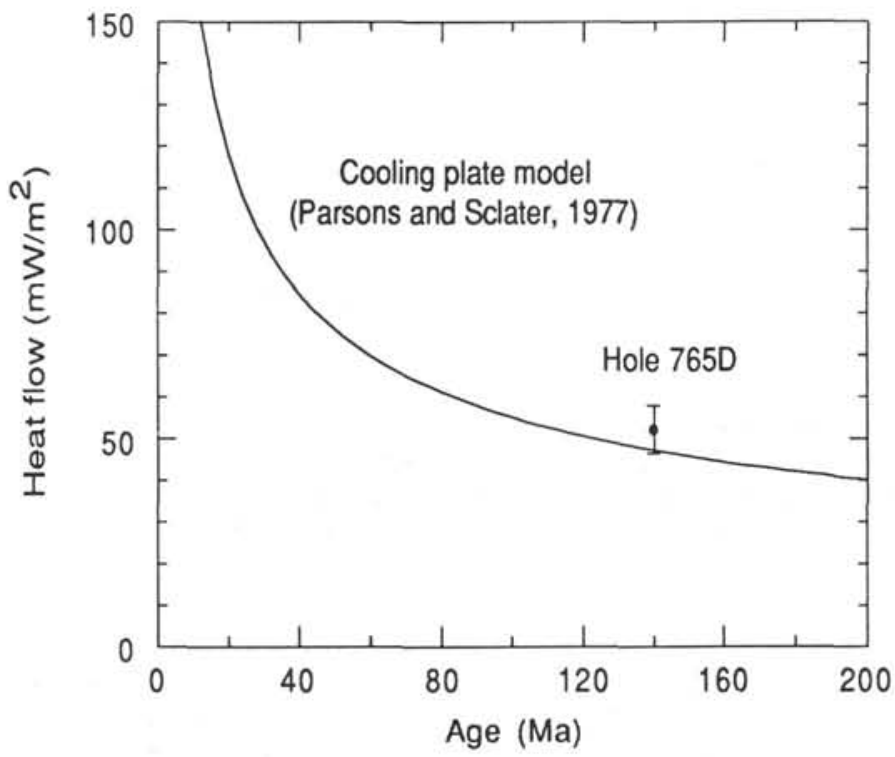

Figure 10. Comparison of Hole 765D heat-flow results and the conductive cooling model of Parsons and Sclater (1977). The result $\left(52 \mathrm{~mW} / \mathrm{m}^{2}\right)$ is higher than that predicted $\left(43 \mathrm{~mW} / \mathrm{m}^{2}\right)$.

into the basalt formation. The proposed explanation is that the upper approximately $200 \mathrm{~m}$ of basement is underpressured (fluid pressure less than hydrostatic), thus forcing seawater into the basalt section (Becker et al., 1984, 1989).

The major difference between Hole 765D and the DSDP holes mentioned here is that a constant temperature profile was not observed within the cased or sediment section of Hole $765 \mathrm{D}$, implying that seawater was not migrating down the borehole. The exact source of these formation fluids at Hole 765D is unclear, but careful examination of the temperature profiles (Figs. 2, 3, and 11) and, in particular, the uppermost thermal inversion near $940 \mathrm{mbsf}$ indicates that cool formation fluids entered the borehole near the casing shoe. The fluid influx could come from the

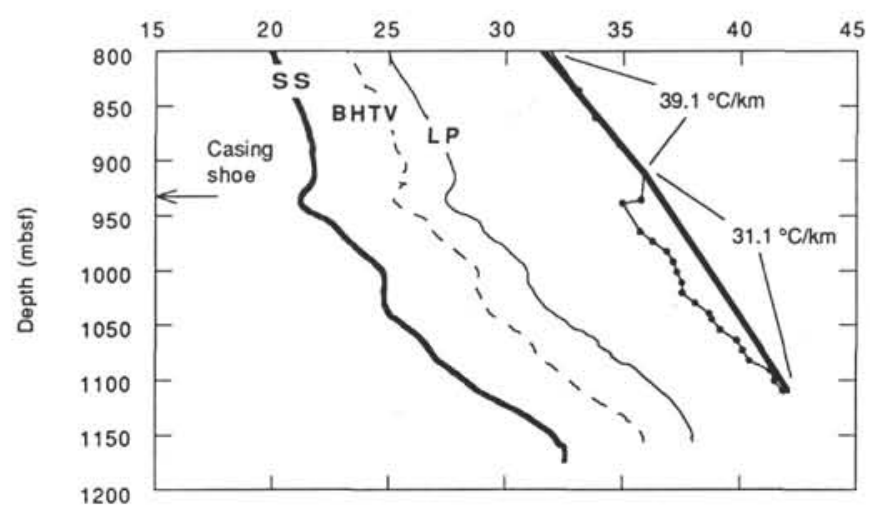

Figure 11. Comparison plot of all the temperature runs, computed equilibrium, and the expected temperatures (solid straight line), based on a constant gradient assuming a uniform heat flow across the sediment/basalt interface. Uniform heat flow was determined from the interval and Bullard methods. Note how the computed equilibrium curve is considerably depressed with respect to the expected temperature profile. The source of this thermal perturbation presumably is related to formation fluids entering the borehole at the casing shoe, flowing down the hole, and entering the formation through faults, fractures, and/or joints. See text for discussion.

sediment/basalt interface ( 930 mbsf) and/or enter the annulus several tens of meters above the casing shoe and flow downward several tens of meters before entering the open-hole section.

Clearly, seawater or formation fluid is entering the borehole near the casing shoe and these same fluids must also have entered the formation elsewhere in the borehole (Figs. 2, 3, and 11). However, as an alternative explanation to fluid flowing entirely into the basalt formation, fluid may also flow out from the formation and back into the borehole. One possible mechanism might be related to the drilling process, during which circulating fluids are forced into the permeable formation at pumping pressures and later flow back into the borehole either after the pumping has ceased and/or after the water was warmed by the formation. This flow-back would also depress the thermal profiles below the recovery to thermal equilibrium predicted for a conductive medium (Beck and Balling, 1988). An example of this can be seen in all three profiles between 1000 and 1050 mbsf (Figs. 3 and 11).

Irrespective of what the detailed flow pattern may be in the basalt section, below the place where fluids are entering at the casing shoe (i.e., $932 \mathrm{mbsf}$ ) the temperature profiles indicate that the formation is permeable and these flow characteristics change little with time. The thermal gradients of the raw temperature data for each run are presented in Figure 12. If the thermal changes were due strictly to drilling, than the sharp, high-frequency gradients for each temperature run would gradually decrease in magnitude and approach a near-equilibrium gradient (Beck and Balling, 1988). On the contrary, there are differences among each gradient that are clearly associated with small spatial and temporal variations that indicate no obvious pattern or trend.

The sharp gradient increase between 930 and 960 mbsf in Figure 12 is due to the continued influx of fluids entering the borehole near the sediment/basalt interface. Below this point, the broad, low gradient centered near 1020 mbsf during the SS run changes character in the subsequent BHTV and LP runs (Fig. 12). Beginning at about $1090 \mathrm{mbsf}$, the SS gradient is moderately erratic, becomes highly irregular during the BHTV run, and then stabilizes to a very smooth profile during the LP run (Fig. 12). This behavior suggests that the thermal disturbances are not strictly due to drilling because these measurements were recorded up to 2 weeks after drilling and circulation had ceased. Rather, the irregular hydrologic property of the upper $200 \mathrm{~m}$ of basalt is 


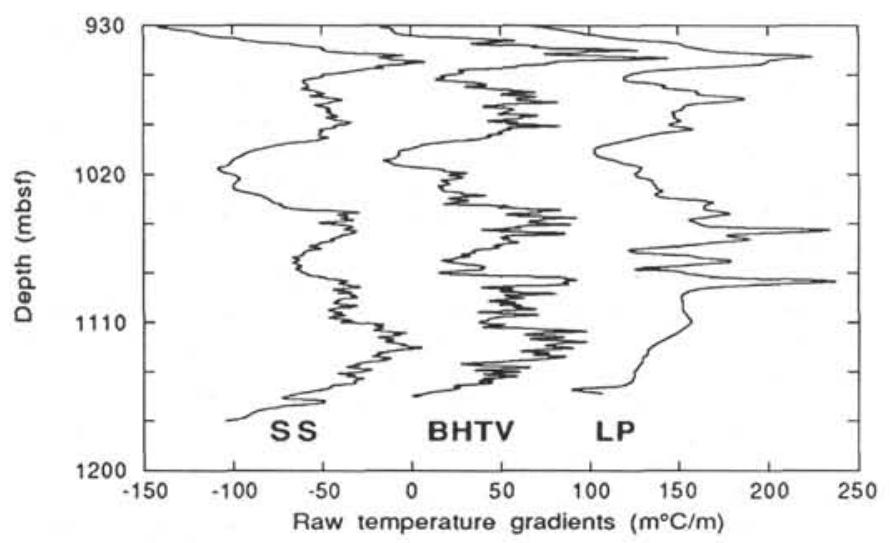

Figure 12. Temperature gradient plots for the SS, BHTV, and LP runs. For clarity, the SS gradient is shifted $100 \mathrm{~m}^{\circ} \mathrm{C} / \mathrm{m}$ to the left and the LP gradient is shifted $100 \mathrm{~m}^{\circ} \mathrm{C} / \mathrm{m}$ to the right. These gradients serve to illustrate how the character of the thermal disturbance varies in space and time. For instance, the profile centered near 1020 mbsf was originally smooth during the SS run, perturbed at a small scale during the BHTV run, and again relatively smooth during the LP run. Other examples occur near 1080 and 1110 mbsf. It appears that during this short observation period (up to 13 days), the well is undergoing nonuniform thermal disturbances.

possibly related to spatial variations of fracture permeability far from the borehole walls. The nature of these variations is largely unknown.

The detailed thermal disturbances observed in Hole 765D raise several important issues regarding the hydrologic properties of this old ( 140 Ma old) oceanic crust. For fluids to flow for extended periods of time ( $>10-14$ days) into the borehole and later into the formation, the oceanic crust at this site is probably permeable and underpressured. Because basalt is inherently associated with low porosity and low permeability, any observed permeability should be related to fracturing within the crust. This appears to be the case in this hole, where an abundance of fractures was seen in the cores and widespread basement alteration was observed in the core samples and in the Schlumberger logs (Ludden, Gradstein, et al., 1990). Anomalously low velocity, density, and resistivity log values indicate that fluids may be migrating through the borehole and along intersected faults, fractures, joints, or boundaries between massive flows or pillows. The fractures within the basalt may also have been induced by drilling due to fluid pressures (either from pumping or lowering the bit near the bottom of the hole) exceeding the minimum stress concentration around the borehole (Castillo and O'Neill, this volume).

In general, the interpretation of temperature measurements in other DSDP/ODP holes suggests that the upper few hundred meters of the crust is permeable. However, permeabilities have been successfully measured in only three DSDP/ODP holes (395A, 504B, and 735B). Bulk permeabilities in the upper $200 \mathrm{~m}$ of the pillow basalts in Hole 504B were found to range from $10^{-13}$ to $10^{-14} \mathrm{~m}^{2}$ (Anderson and Zoback, 1982; Becker et al., 1983). Hickman et al. (1984) reported that permeabilities measured at the bottom of Hole $395 \mathrm{~A}$ were on the order of $10^{-18} \mathrm{~m}^{2}$. Unfortunately, attempts to measure the permeability with inflatable packers in Hole 765D were unsuccessful.

The source of the underpressuring at this site is unclear. Simulations of convection in the oceanic crust at Hole 504B (Williams et al., 1986) demonstrate that surface heat flow, temperature profiles, and underpressuring can occur when the permeability changes as a function of depth and the basement rocks are overlain by an impermeable cap such as a chert layer. Chert was not observed at Site 765; however, Unit D (590-896 mbsf) showed normal compaction trends with increasing bulk densities and decreasing water content and porosity (Ludden, Gradstein, et al., 1990). Although these characteristics are not directly interpretable in terms of assigning low permeability to this section, they do suggest that permeability is likely to decrease with increasing compaction unless, of course, fracture permeability is active.

Hole $765 \mathrm{D}$ was left in excellent condition for reentry. If drilling were to be continued at this site, obtaining another finescale temperature profile prior to drilling would test the long-term hydrologic and thermal properties of $\sim 140$-Ma-old oceanic crust. The remaining outstanding questions that could be addressed with subsequent temperature and permeability measurements are the following: will remeasured temperature profiles be representative of true thermal equilibrium conditions and will the apparent underpressuring dissipate with time and become hydrostatic?

\section{CONCLUSIONS}

Fine-scale, high-resolution temperature profiles from 1200-m Hole 765D situated in $\sim 140$-Ma-old oceanic crust indicate that the average heat flow throughout the sediment section (0-932 mbsf) is about $52.8 \pm 5.7 \mathrm{~mW} / \mathrm{m}^{2}$ (based on the interval method). This heat-flow result is slightly higher $\left(\sim 9 \mathrm{~mW} / \mathrm{m}^{2}\right)$ than both the regional heat flow for the Argo Abyssal Plain area and the heat flow predicted for a conductively cooling model. Because the site is situated near the continent/ocean boundary, the additional heat source may be continental in nature, radiating outward from the margins of northwestern Australia. The basalt section (932-1200 mbsf), however, is thermally perturbed and associated with temperature inversions and intervals $(10-50 \mathrm{~m})$ of near-constant temperature. The computed equilibrium temperature profile for the basalt section is depressed in excess of a few degrees Celsius compared with an expected profile assuming a conductive and steady-state heat-flow regime. Apparently, the source of this thermal perturbation is cool formation fluid entering the borehole near the sediment/basalt interface, flowing downhole, and later entering the basalt formation presumably through open fractures. Based on these thermal and hydrologic observations, the upper 150 -m section of the oceanic crust is believed to be permeable and slightly underpressured (fluid pressure less than hydrostatic).

\section{ACKNOWLEDGMENTS}

The collection and analysis of this temperature data set would not have been possible if it were not for C. Williams and others at the Borehole Research Group at LDGO. I am grateful to K. Becker, A. Fisher, M. Magee, M. Mareschal, C. Williams, R. Nolen-Hoeksema, and an anonymous reviewer for greatly improving this manuscript.

\section{REFERENCES}

Anderson, R. N., and Hobart, M. A., 1976. The relation between heat flow, sediment thickness, and age in the eastern Pacific. J. Geophys. Res., 81:2968-2989.

Anderson, R. N., Langseth, M. G., and Sclater, J. G., 1977. The mechanism of heat transfer through the floor of the Indian Ocean. $J$. Geophys. Res., 82:3391-3409.

Anderson, R. N., and Zoback, M. D., 1982. Permeability, underpressures, and convection in the oceanic crust near the Costa Rica Rift, eastern equatorial Pacific. J. Geophys. Res., 87:2860-2868.

Beck, A. E., and Balling, N., 1988. Determination of virgin rock temperatures. In Haenel, R., Rybach, L., and Stegena, L. (Eds.), Handbook of Terrestrial Heat Flow Density Determination (1st ed.): Boston (Kluwer Academic), 59-85.

Becker, K., Langseth, M. G., and Hyndman, R. D., 1984. Temperature measurements in Hole 395B, Leg 78B. In Hyndman, R. D., and Salisbury, M. H., et al., Init. Repts. DSDP, 78B: Washington (U.S. Govt. Printing Office), 689-698. 
Becker, K., Langseth, M. G., Von Herzen, R. P., and Anderson, R. N., 1983. Deep crustal geothermal measurements, Hole 504B, Costa Rica Rift. J. Geophys, Res., 88:3447-3457.

Becker, K., Sakai, H., Adamson, A. C., Alexandrovich, J., Alt, J. C., Anderson, R. N., Bideau, D., Gable, R., Herzig, P. M., Houghton, S., Ishizuka, H., Kawahata, H., Kinoshita, H., Langseth, M. G., Lovell, M. A., Malpas, J., Masuda, H., Merrill, R. B., Morin, R. H., Mottl, M. J., Pariso, J. E., Pezard, P., Phillips, J., Sparks, J., and Uhlig, P., 1989. Drilling deep into the oceanic crust at Hole 504B, Costa Rica Rift. Rev. Geophys., 27:79-102.

Bullard, E. C., 1939. Heat flow in South Africa. Proc R. Soc. London A, 173:474-502,

1947. The time necessary for the borehole to attain temperature equilibrium. Mon. Not. R. Astron. Soc., Geophys. Suppl., 5:127-130.

Geller, C. A., Weissel, J. K., and Anderson, R. N., 1983. Heat transfer and intraplate deformation in the central Indian Ocean. J. Geophys. Res., 88:1018-1032.

Hickman, S. H., Langseth, M. G., and Svitek, J. F., 1984. In situ permeability and pore-pressure measurements near the Mid-Atlantic Ridge, Deep Sea Drilling Project Hole 395A. In Hyndman, R. D., Salisbury, M. H., et al., Init. Repts. DSDP, 78B: Washington (U.S. Govt. Printing Office), 699-708.

Hyndman, R. D., Von Herzen, R. P., Erickson, A. J., and Jolivet, J., 1976. Heat flow measurements in deep crustal holes on the Mid-Atlantic Ridge. J. Geophys. Res., 81:4053-4060.

Hyndman, R. D., Von Herzen, R. P., Erickson, A. J., and Jolivet, J., 1977. Heat flow measurements, DSDP Leg 37. In Aumento, F., Melson, W. G., et al., Init. Repts. DSDP, 37: Washington (U.S. Govt. Printing Office), 347-362.

Lachenbruch, A. H., and Brewer, M. C., 1959. Dissipation of the temperature effect in drilling a well in Arctic Alaska. U.S. Geol. Surv. Bull., 1083:73-109.

Langseth, M. G., Mottl, M. J., Hobart, M. A., and Fischer, A., 1988. The distribution of geothermal and geochemical gradients near Site
501/504: implications for hydrothermal circulation in the oceanic crust. In Becker, K., Sakai, H., et al., Proc. ODP, Init. Repts., 111: College Station, TX (Ocean Drilling Program), 23-32.

Ludden, J. N., Gradstein, F. M., et al., 1990. Proc. ODP, Init. Repts., 123: College Station, TX (Ocean Drilling Program).

Parsons, B., and Sclater, J. G., 1977. An analysis of the variation of ocean floor bathymetry and heat flow with age. J. Geophys. Res., 82:803827.

Powell, W. G., Chapman, D. S., Balling, N., and Beck, A. E., 1988. Continental heat-flow density. In Haenel, R., Rybach, L., and Stegena, L. (Eds.), Handbook of Terrestrial Heat Flow Density Determination (1st ed.): Boston (Kluwer Academic), 167-222.

Stein, C. A., Hobart, M. A., and Abbott, D. H., 1988. Has the Wharton Basin's heat flow been perturbed by the formation of a diffuse plate boundary in the Indian Ocean? Geophys. Res. Lett., 15:455-458.

Swift, M. G., Stagg, H.M.J., and Falvey, D. A., 1988. Heat flow regime and implications for oil maturation and migration in the offshore Northern Carnarvon Basin. In Purcell, P. G., and Purcell, R. R. (Eds.), The North West Shelf, Australia. Proc. Pet. Explor. Soc. Aust. Symp., 539-552.

Uyeda, S., and Horai, K., 1982. Heat flow measurements on Deep Sea Drilling Project Leg 60. In Hussong, D. M., Uyeda, S., et al., Init. Repts. DSDP, 60: Washington (U.S. Govt. Printing Office), 789-800.

Veevers, J. J., Tayton, J. W., and Johnson, B. D., 1985. Magnetic expression of the continent-ocean boundary between the western margin of Australia and the eastern Indian Ocean. J. Geophys., 56:106-120.

Williams, C. F., Narasimhan, T. N., Anderson, R. N., Zoback, M. D., and Becker, K., 1986. Convection in the oceanic crust: simulation of observations from Deep Sea Drilling Project Hole 504B, Costa Rica Rift. J. Geophys. Res., 91:4877-4889.

Date of initial receipt: 3 August 1990

Date of acceptance: 10 July 1991

Ms 123B-135 